\title{
The worth of natural light
}

Received: 27th September, 2005

\section{Andrew D. Thompson MRICS, FRGS}

is a chartered environmental surveyor and a partner in Wilks Head \& Eve, a firm specialising in rights of light and environmental issues associated with natural light encountered in the development process. He is a member of the RICS Boundary and Party Wall Group, which is responsible for rights of light matters and was the winner of the IRRV Innovations in Valuations Award in 2004, for his paper 'The development value of light'.

\begin{abstract}
Ransom in a negotiation traditionally has been accepted in rights of light, however, the recent ruling in Mid-Town $v$ City of London Real Property Company [2005] EWHC33 (CH) challenges both this style of negotiation and the legal basis that has allowed parties to benefit financially from another development's aspirations. The developer awaits the inquiry into costs in this case and the issue of debate now is how will the court calculate the worth of a rights of light injury?

The public attention that has been generated, due to this case, has brought light valuation methods into the open from what historically has been a closed area of professional practice frequented by only a few. This new focus on light has led some to ask if this method of valuation could hold the key to a new source of local government taxation based on the level of development profit.
\end{abstract}

\section{Keywords:}

rights of light, valuation, environmental pollution, easements, local government taxation

\section{INTRODUCTION}

It is now over 100 years since the landmark right of light case of Colls $v$ Home and Colonial Stores Company Limited [1904] AC179. Recent events in the High Court, however, have shown that modern-day judges are just as prepared to look afresh at the ancient right of light, and bring this easement into a current-day perspective. Ransom or blackmail traditionally are not considered dirty words in rights of light circles (Anstey, 1988). The aim in a commercial negotiation has been to present the threat of the risk of injunction, then negotiate from this position of strength. Therefore, the background to the events, which led to the recent case of Mid-Town $v$ City of London Real Property Company Limited [2005] EWHC33 (CH), is not immediately of any special note. Land Securities, via one of its subsidiary companies, was seeking to develop the

Wilks Head \& Eve 9 Harley Street London W1G 9AL, UK Tel: +44 (o) 2076378471 Fax: +44 (o) 2076310536 E-mail: athompson@wilks-head.co.uk New Street Square site located in the City of London. The adjoining owners, a firm of solicitors, sought to hold the scheme to ransom by seeking an injunction to force the payment of, what can be assumed, considerable compensation for the release of what was believed at the time to be an injunction position. The right of light held by Mid-Town was 
not in dispute between the parties. The trial argument turned on the point of whether an adjoining owner had an automatic right to injunctive relief when faced by serious light loss. The arguable case existed that the affected party did not seriously desire to protect their light, but was misusing the right as a negotiation point to seek a ransom payment. The case therefore becomes of interest due to the fact that the court refused the request for an injunction due to this misuse of the legal process. The matter is now awaiting an inquiry into costs, and therefore this case potentially will provide the clarification sought by rights of light practitioners as to the correct method of valuation to be used in a central business district light injury.

\section{The last 100 years of professional practice}

\section{HISTORY OF LIGHT VALUATION}

In order to understand the current-day assumption used in light valuation, it is necessary to place the method into the context of the last 100 years of professional practice. While Colls $v$ Home and Colonial Stores Limited [1904] AC179 established the legal basis, the technical and valuation issues took slightly longer to develop. The first advance was made by Percy Waldram, FRICS who presented a paper to the Chartered Surveyors Institution (now the Royal Institution of Chartered Surveyors) on 5th March, 1928. The method discussed, which now bears his name, is still the theoretical justification for the calculation of the 'before' and 'after' positions of the 0.2 per cent sky factor (Waldram, 1928). The Waldram diagram with the associated method of establishing a light injury were accepted in the Mid-Town ruling by both experts and the court. This has continued the now long-running practice of the courts to accept this method as suitable in rights of light cases. The rationale used in the method is that if 1/500th of the light available from an unobstructed hemisphere of uniform sky on a flat surface is plotted as a contour within an existing room, this would provide the equivalent illumination of a $1 \mathrm{ft}$ standard candle, which is considered by the method as just enough light to use to read the printed text of a broadsheet newspaper (Hopkinson et al., 1966). This method was developed into a formal method of valuation by George Lesley Head of Head \& Co (now known as Wilks Head \& Eve), who presented his paper to the Chartered Surveyors Institution on Monday 10th May, 1937 (Head, 1937). The introductory words to that paper effectively set out the basis for what has become the current method of valuation.

\footnotetext{
'Modern development by high buildings in already densely built-up areas frequently causes a loss of light to the older buildings around them, and consequently the buildings sometimes suffer damage by loss of rent ...
}

Therefore, since 1937 the basis of light compensation calculations has used the rationale of the Light Standard Rent $\left(\mathrm{L}_{\mathrm{SR}}\right)$ as the foundation stone from which to value the worth of a natural light injury. The light valuation can be summarised in the current-day application of this method by the following basic formula. 


$$
\operatorname{Comp}=\mathrm{E}_{\mathrm{fz}} \mathrm{VL}_{\mathrm{sr}} \mathrm{P}_{\mathrm{u}}
$$

Where

$\mathrm{E}_{\mathrm{fz}}=$ Equivalent Front Zone

$\mathrm{V}=$ Present value of $£ 1$ per annum

$\mathrm{E}_{\mathrm{fz}}=$ Light Standard Rent

$\mathrm{P}_{\mathrm{u}}=$ Parasitic Uplift (cf. Carr-Saunders v Dick McNeil Associates Limited [1986] 2 All ER 888 p. 896)

The method uses measurements in imperial $£$ per square foot as this was the accepted unit of property valuation measurement applicable in 1937. The method was fine-tuned by the late John Anstey, FRICS in the 1980 s, and he is credited with the development of the method into the workable valuation technique employed by the current generation of light surveyors (Anstey, 1981).

\section{Example}

National Light Pollution The Natural Light Pollution $\left(\mathrm{N}_{\mathrm{LP}}\right)$ created by the developer's obstruction creates an $\mathrm{E}_{\mathrm{FZ}}$ loss of 500 square feet. The adjoining property that suffers from the $\mathrm{N}_{\mathrm{PL}}$ is owned by three legal interests:

- The freeholder

- The investment fund (head leasehold) for 60 years

- The occupying tenant of 15 years.

It has been assumed in the above that the head lease and occupying tenant are on upward-only rent reviews. The light surveyors negotiated an $\mathrm{L}_{\mathrm{SR}}$ of $£ 3.50$ based on central business zone rents within a regional centre. The $\mathrm{P}_{\mathrm{U}}$ was agreed to represent the case law example of 2.65. Market evidence shows an expectation of $18 \mathrm{YP}$ or a rate of 5.5 per cent.

Total compensation

Head leasehold at 60 years

Tenant at 15 years

$$
\begin{aligned}
& =\mathrm{E}_{\mathrm{FZ}} \mathrm{V} \mathrm{L}_{\mathrm{SR}} \mathrm{P}_{\mathrm{U}} \\
& =500 \times 18.1818 \times 3.5 \times 2.65 \\
& =£ 84,318.10 \\
& =500 \times 17.4499 \times 3.5 \times 2.65 \\
& =£ 80,923.91 \\
& =500 \times 10.0376 \times 3.5 \times 2.65 \\
& =£ 46,549.37
\end{aligned}
$$

Therefore, allowing for the three interests, the compensation split between the parties is as follows.

$$
\begin{aligned}
\text { Compensation to freeholder } & =84,318.10-80,923.91 \\
& =£ 3,394.19 \\
\text { Compensation to head leaseholder } & =80,923.91-46,549.37 \\
& =£ 34,374.54 \\
\text { Compensation to tenant } & =£ 46,549.37
\end{aligned}
$$


The logic of this method is based on compensating the loss of light suffered to the affected property, based on that element of the rental figure being paid in appreciation of the light enjoyed by the affected property before the development was undertaken. Therefore, the person being compensated is simply being reinstated to the financial worth of their rental area, had the development never taken place.

\section{CHALLENGING THE LIGHT STANDARD RENT APPROACH}

An earlier alternative method of valuation known as the 'Whole Building Method' was dismissed by the late John Anstey, FRICS (1988) as follows:

\footnotetext{
'The whole building method is useful however, in dealing with those who argue that because of its prime position the building has not actually suffered any loss in value because of its loss of light: those who put forward this argument also like to say that their new building has increased values in the neighbourhood, and that for that reason no loss has occurred - quite the contrary in fact. Your building, or your clients' building, they argue, has actually had its value enhanced by their development: so why are you claiming? Ask such a person to imagine two absolutely identical buildings, both improved by their new neighbour, and both enjoying all the same benefits except one: the light of one is the new conditions, the light of the other is the old. Would your adversary bid the same by way of capital or rent for the two properties? If he says that he would, you might as well give up talking to him and see him in Court. If he honestly replies that he would not, you explain that your valuation exercise is directed at finding out by how much his bid for one should exceed his bid for the other. The answer equals the loss suffered.'
}

\section{New research challenges old wisdom}

This wisdom has remained unchallenged until now. Research outside of the traditional surveying and valuation community is providing a new insight in support of the whole building method argument (Davies, 2005). This alternative view is provided by urban geographers researching the potential for a major sports stadium to be used as a method of urban regeneration. The research considered the objector argument commonly presented at the planning application stage that property values in the immediate area of a stadium would diminish in value. The research found in the case studies of both Manchester and Cardiff that property values increased. The stadia, it was suggested, were acting as a focal point of urban regeneration.

\footnotetext{
'Although the research presented in the paper has limitations, it has provided some evidence to suggest that in contrast to prevailing assumptions, sports stadia can have a positive impact on residential values in the surrounding area' (Davies, 2005).
}

This restatement of the factual basis to the whole building method does create a fresh need for research and review. If the light obstruction building is classified as a landmark building within an urban regeneration project should the $\mathrm{N}_{\mathrm{LP}}$ be discounted if, when viewed from a whole building valuation of the regeneration, it creates a positive increase in the asset worth of all property in the locality? Is it right and just to forget an individual item of loss if in the holistic environmental context the whole system will benefit even though one element suffers serious loss?

While one piece of isolated valuation research alone is unlikely to be sufficient for the courts to depart from accepted practice, if additional 


\section{The environmental context}

evidence is found linking improvements to central business districts' rental value and high mass development, the old counter argument to any compensation payment might discover a new lease of life. In a recent press release to Property Week, the expert acting for Land Securities hinted that the nil compensation argument might be presented in this case.

It is therefore clear that one party is investing hope and resources in the further investigation of the whole building argument and as they have surprised everyone in the initial ruling it would be wrong to underestimate their chance of success.

\section{N LP IN THE ENVIRONMENTAL CONTEXT}

The ancient easement of light can be seen as an attempt by our forefathers to protect and preserve what was, before artificial lighting, a vital feature of basic property need. It is therefore easy when discussing the worth of light to see the easement in basic financial terms. The rules that have, through time, been created to define the right of light on the whole cannot be said to have been motivated by environmental pollution as defined in current legislation. Light surveyors express the issue via financial compensation or injunction rather than the traditional view of environmental damage. If system thinking is applied to the problem and natural light is considered in the holistic environmental context, however, its vital importance could allow the right of light to be redefined.

First, natural light needs to be understood as being a full element of the sustainable development concept. The need for good passive solar design and effective use of daylight in properties to reduce $\mathrm{CO}_{2}$ omissions, in terms of achieving the national property stocks targets alone, is capable of a 50 per cent reduction in the goal figure for space heating in housing stock case studies (Littlefair, 1998). Therefore, the obstruction of a welldaylit property that will result in any increase in artificial light use is creating $\mathrm{N}_{\mathrm{LP}}$ by the holistic environmental logic. The pollution is due to the creation by the obstruction of a set of circumstances that will result in an increase in the $\mathrm{CO}_{2}$ footprint of the adjoining property. This is created by the loss of passive solar gain and the additional load burden due to increased artificial lighting need.

Artificial light use was presented as an argument by Land Securities to justify the award of compensation in lieu of an injunction. This therefore provides the court with the opportunity of considering the implications and burden of this new lighting loading both on the occupier and on society. It is now accepted in official energy efficiency policy documents that daylight can be zoned with artificial lighting to reduce a building's energy demand. Therefore, the logical link must follow that an obstruction reduces energy efficacy. 


\section{Technology makes it easier to determine safe light profile}

If the link between light obstruction and environmental pollution is accepted as being technically correct then the valuation can follow the logic of environmental economics. This has an accepted core concept of the 'polluter pays principle' (PPP). The party creating the $\mathrm{N}_{\mathrm{LP}}$ is seen as a 'freeloader' benefiting from the pollution burden they impose on society and individuals. The action of the court to impose substantial levels of compensation therefore, is a correction measure in the market to address the freeloader's pollution.

The concept of a developer's profit approach to compensate for the compulsory removal of a legal right can find support in the lead valuation case of Stokes v Cambridge Corp (1961) 13 P\&CR77 (Denyer-Green, 2003).

Due to technology it is now easier on major commercial schemes to determine the safe light profile that a development can build under before creating a right of light injury (Chynoweth, 2004). Once this envelope is established the extent and profit of any additional massing is established with the extent and profit of the extra mass becoming a simple matter of the application of established property valuation techniques. The issue therefore in the environmental context is the question: Is a percentage of the profit sufficient to justify the PPP or, in addition to the base profit, should an additional payment be made to compensate for the new additional running costs to the adjoining property which result from the loss of passive solar gain and need for electric lighting to replace the lost daylight? If the adjoining ownerfriendly viewpoint is adopted a valuation method based on the following formula could be argued.

$$
\text { Comp }=(\mathrm{A} \mathrm{VW} / 2)+\mathrm{E}_{\mathrm{ng}}
$$

Where

$A=$ Extent of developer's increase in gross cubic massing $\left(\mathrm{m}^{3}\right)$

$\mathrm{V}=$ Present value of $£ 1$ per annum

$\mathrm{W}=$ Worth in open market value of A of development

$\mathrm{E}_{\mathrm{ng}}=$ Average energy cost for a five-year period of adjoining owner's building $\times$ Correction factor for artificial lighting to room numbers facing proposed development $x$ increase in energy burden.

While the calculation of $E_{n g}$ at first may appear a new concept it is based on the well-established formula used in energy efficiency calculations. The hypothesis presented is that if a building's energy efficiency can be calculated then the inverse, which is the inefficiency generated by the $\mathrm{N}_{\mathrm{LP}}$, should also be capable of calculation. This inefficiency is believed to be due to the development mass moving outside the right of light profile and thereby creating an $\mathrm{N}_{\mathrm{LP}}$ situation.

This method therefore compensates for the loss of the legal right via a percentage of the developer's profit and the direct loss suffered by the adjoining owner who now has additional energy costs due to the loss of 


\section{Potentially viable method of green taxation}

natural light to their building. The calculation has been designed so that the developer pays more in compensation than they receive in benefit. This is in line with the environmental concept of PPP. Developers would then be forced to reassess the risk/benefit balance of a scheme and the justification of creating an $\mathrm{N}_{\mathrm{LP}}$ damaging property would have an economic argument in favour of a more green and sustainable development-friendly design.

\section{LIGHT AS GREEN TAXATION}

The Institute of Revenue Rating and Valuation (IRRV) Conference in 2004 provided a melting pot for a wide-ranging mix of parties to meet and challenge accepted thinking. The environmental impact of developers via $\mathrm{N}_{\mathrm{LP}}$ was identified by delegates as a potentially viable method of green taxation that could be linked to the local authority planning controls function and collected as part of a review of local government funding (Thompson, 2005).

In terms of approach and method, if the worth of light is separated from the legal easement of light, then a method of development taxation based on the environmental impact of a high mass scheme could be used by a local planning authority to encourage or dissuade $\mathrm{N}_{\mathrm{LP}}$ design in sensitive areas. This method would be difficult to justify if the courts award a profit-based compensation method but in the event of a nil award the environmental case for a corrective taxation measure would strengthen. There is the potential for a developer to win the battle fought in the case but still lose the war in the long term due to the introduction of corrective taxation.

\section{CONCLUSION}

The court will have a range of possible solutions to review when considering the matter of the worth of light. The award of nil compensation in practical terms will destroy the status of the easement of light in the central business district context. Until a follow-on residential case is heard the difference between a commercial office and a residential property is sufficient to allow an arguable case to be presented to justify the two situations as separate legal concepts. Therefore, in this author's view, a nil ruling could still maintain rights of light as a limited residential concept.

If encouraged by both the parties' appointed experts, the court could maintain and support the status quo method as used since 1937. While not perfect, it is understood and accepted within the property industry by experts, developers and commercial property asset managers.

Most radical of all, the court could provide robust guidance that natural light has a significant environmental and social worth. This worth being reflected in a substantial award of damages based on a high percentage of the developer's profit. This ruling will be awaited not only by developers and property owners but also by environmentalists as an insight into whether the sustainable development message has reached today's legal system. 


\section{References}

Anstey, J. (1981) The Valuation of Rights of Light, Property Valuation Handbook B4, College of Estate Management, Reading, UK.

Anstey, J. (1988) Rights of Light and How to Deal With Them, Surveyors Publications, RICS, London, UK.

Chynoweth, P. (2004) 'Progressing the rights to light debate - Part 1: A review of current practice', Structural Survey, 22(3), 131-1317.

Davies, L.E. (2005) 'Not in my back yard! Sports stadia location and the property market', Area, 37(3), 268-276.

Denyer-Green, B. (2003) Compulsory Purchase and Compensation, 7th edn, Estates Gazette, London, UK.

Head, G.L. (1937) The Rental Value of Light. Ordinary General Meeting of the Chartered Surveyors' Institution, Monday 10th May, JB Nichols and Son Limited, London, UK.

Hopkinson, R.G., Petherbridge, P. and Longmore, J. (1966) Daylighting, WH Heinemann, London, UK.

Jansen, M. (2005) 'Test case sheds new light', Property Week, 17th June, 62-65.

Littlefair, P. (1998) Passive Solar Urban Design: Ensuring the Penetration of Solar Energy into the City. Renewable and Sustainable Energy Reviews, Pergamon, London, UK, pp. 303-326.

Thompson, A.D. (2005) 'Rays of hope', IRRV Valuer, 12-14, IRRV Publications Department, London, UK.

Waldram, P. (1928) The Estimation of Damage in Ancient Light Disputes. Ordinary General Meeting of the Chartered Surveyors Institution 5th March, London, UK. 